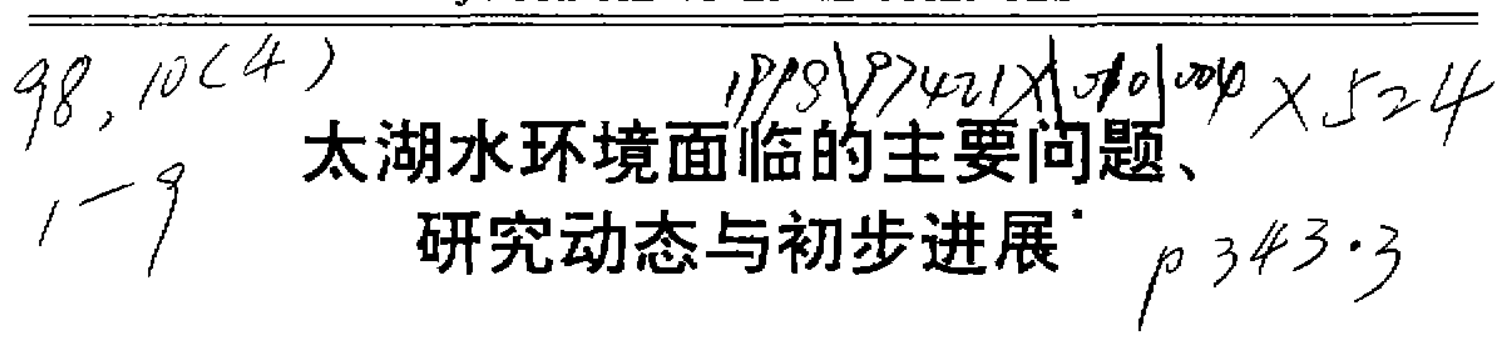

\author{
秦伯强 \\ (中国科学院南京地理与湖泊破究所,南京 210008)
}

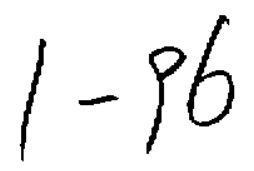

提是本文对太湖水环境研究作了一个首单的回顾. 指出了这几十年工作所取得的成

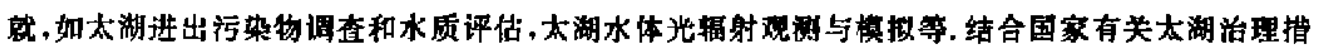

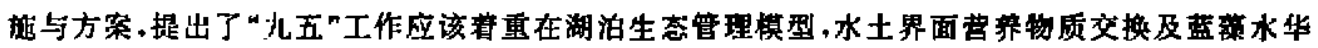
熳发扎籼等领城. 通过对当前国际上在这些领域中研究进展情况的回宣，特别介绍了在湖泊水动

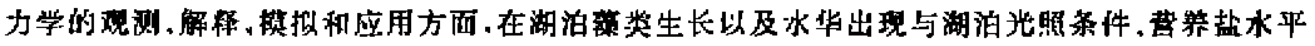

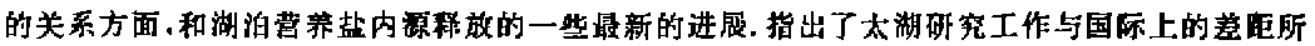
在.最后,对“九无”期间开展工作所取得的初步成果作了一简要的总结.

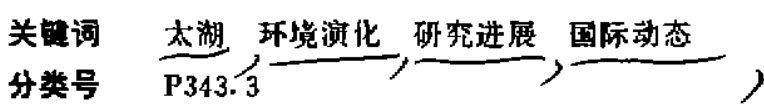

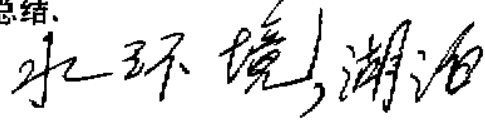

太湖是我国著名的淡水湖泊. 位于中国经济发致较块的长江下游三角洲地区. 该地区人口 密度大, 城市化程度高. 太湖又是上海, 苏州、无锡等大、中城市的水源地. 但近年来, 随着经济 的发展,污染的加重,湖泊富营养化日趋加剧. 现在几乎每年夏天均有蓝蕚水华暴发, 严重地影 响着无锡市供水. 国务院于 1996 年在无钽太湖召开了现场会议,提出了太湖治理的方法与措 批. 即到 2000 年太湖流域主要出入湖河流的水质要达到国家地面水类水质标准,使太湖水 变清; 到 2010 年基本解尤太湖富营养化问题,湖区生态系统转向良性循环(1).实际上,太湖的 环境问题是有普遍性的. 因为在我国东部众多的平原湖泊中,绝大多数湖泊正面临着与太湖相 类似的问题. 因而,对太湖水环境问题开展研究,有着重大的实际意义与推广们值. 本文试图对 太湖水环境研究中的几个突出的问题、及与这些问题相联系的国内、国际研究现状予以阐述. 最后，归纳总结了“儿五”频间在太湖开展的科研工作所获得的一些阶段性认识与进展.

1 太湖水环境研究回顾与当前面临的主要问题

关于太湖的研究, 最早可以上湖到本世纪三十年代 ${ }^{[1]} .1949$ 年后, 中国科学院南京地理研 究所联合多家单位一起于 1960 年对太湖进行了一次全面系统的调查, 基本摸清了太湖地区的 构造状况、湖区水文气象、水生动植物、水化学与沉积物组成。根据当时的调查结果，总无机奥 与总元机磷浓度一般在 $0.05-0.09 \mathrm{mg} / \mathrm{L}$ 和 $0.01-0.05 \mathrm{mg} / \mathrm{L}^{[2]}$. 对于湖流的调查显示湖流平 均仅 $0.1-0.3 \mathrm{~m} / \mathrm{s}$, 在要季偏南风作用下, 湖流以平台山为中心, 形成一个逆时针环流 ${ }^{[2]}$. 当时

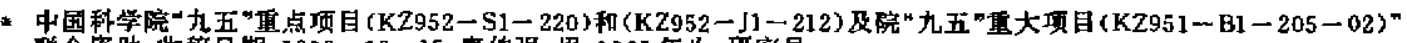

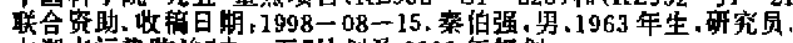

(1) 太湖水污染陟治一五”计划及2010年规划<smiles>C=CC</smiles> 
湖泊底质中营养盐成份很低，不存在内源污染的问题 ${ }^{[2]} .1984-1986$ 年中日合作太湖考察项 目首次进行了太湖湖流、波浪与悬浮物质等的观察，取得了大量数据、“七五”与“人五”期间， 随者太湖水环境的㦞化,有关污染方面的问题也突显出来,先后进行了“太湖出入湖河道污染 物总量及太湖环境容最的研究";“东太湖局部水域水质照化原因及其防治对策研究”，“太湖生 态环境与污染源调查"等项目、这些研究项目所取得的贡胴归纳起来可以有以下几点:(1) 首

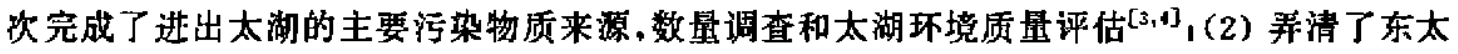
湖地区的水产美殖对水环境影响及其大小 ${ }^{[5.6] ，(3)}$ 首次进行了湖泊光物理学的观利与模拟， 以及生物可利用光强度和湖水黄质, 悬浮物质等的关系 ${ }^{[7.8]}$; (4) 琴清楚了太湖水生生物与植 物种群状况及其初步的演变情况 ${ }^{[0,10]}$ （5）把遥感与 GIS 技术应用于水环境研究，拓展了物理 湖泊学研究的内涌 ${ }^{[1]} ，(6)$ 提出了物理生态工程的思想,并在实践中加以发展完善 ${ }^{[12]}$; 该工程 的科学基础实际上是生物调控技术 ${ }^{[13]}$. 上述成果使得人们对太湖水环境与生态环境系统的现 状与发展有了一个协步完整的认识.

进入“九五”以后, 由于污染形势的进一步发展, 太湖水环境问题已经引起了从中央到地方 各级政府的重规. 由国家环境保护局联合国家计委、水利部及江苏、浙江、上海二省一市有关部 门制定的太湖污染防治“九五”计划及 2010 年规划中, 分别就污染控制排放, 1998 年达标行动 计划, 2000 年太湖水变清行动计划和 2010 年太湖中营养达标规划中提出了具体行动计划. 内 容包括了底泥䟽浚示范工程和蓝㩰水华收集与顽防措施. 对于底泥疏浚, 当前需弄清楚的是太 湖内源污染程度有多大, 疏㴒之后, 能在多大程度上解决问题. 爱回答这些部问题, 必须开展太 湖水一土界面营养物质交换与营养盐的循环方面和研究. 关于蓝棌水华问题, 必须研究蓝落暴 发与环境、物理、化学等因子的关系,水华的漂移与堆积必须与湖泊流场结构研究结合起来. 因 此，“九五.”期间, 由中国科学院资助, 由太湖湖泊生态系统研究站牵头的大部分科研项目基本 上都是围绕普上述生产实际中急需解决的问题而开展的, 即通过研究水一土界面营养物质交 换来回答内源污染的大小和底泥硫涹后的效果; 通过研究蓝营水华暴发的机理来回答水华防 治与控制的措旅; 通过建立以湖泊水动力学为基础，迭加了菜类、莒养盐、量浮物质迁移和扩散 等讨程的太湖水环境管理楼型来建立太湖水华暴发、㙫积的预测模型.

\section{2 国内外研究动态}

\section{1 物理湖泊器}

展望国际上在上述相关领域内的研究, 可以知道目前国内的差距所在. 湖泊水动力学研究 是物理湖泊学的一个重要内容. 但这是一个较为困难的领域. 其困难性主要是资料不易获得. 同物理海洋学的观测一样、湖泊中的波浪、湖流等要素在时间、空间上同步,长系列及高分辨率 的观测仍有很大难度. 这在大型湖泊中尤为如此. 即使能㓩收集到这些资料，如何分离各种各 样的动力因子 (风驱动力, 湖岸䀘射流, 密度不均造成的重力流及地球自转的科里奥力等)造成 的湖流与波动特征也非易事. 以往我们常常用风场驱动或吞吐流等一级作用力来解释, 显然是 很柤糙的。只能解释一定时期，一定条件下某种主导型的流与波浪的特征,对于次一级的过程 与特征,蚗乏研究、国际上, 早在六、七十年代开展的国际大湖调查年中, 对北美安大略湖进行

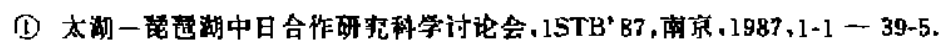


的水䢵力学研究支持了许多新的理论与假设 ${ }^{[14]}$. 其中之一获是被广泛认可的“湖盆模式” (“Basin Modes”或者“Seiches”)，该模式被用来解释日本琵琶湖 ${ }^{[15]}$, 德国 Constance 湖 ${ }^{[16]}$, 瓶 士日内瓦湖 ${ }^{[17]}$ 、苏黎世湖 ${ }^{[18]}$ 与 Lugano 湖 ${ }^{[19]}$ 的湖流与内波特征.

湖泊水䢵力学模拟也是该领域的一个重要组成部分. 这一方面应首先归功于大气科学与 物理海洋学的数植模拟的发展、较之大气与海洋物理问题,湖泊中的物理描述方程要简单得 多. Hutter 在 1991 年对于湖泊水动力学方程组给出了不同类型湖泊及特定条件下方程组的 简化,物理解释与适用范围 ${ }^{[19]}$. 在计算方法上,Casulli 于 1990 年在第八届国际水力学计算大 会上，就二维浅水湖泊水动力学的差分计算,对目前国际上较为流行的“变化方向隐含法” (Alternation Direction Implicit), 传统的半隐含法与全隐含法等差分格式进行了总结, 讨论各 自的优虹点. 事实上,随着计算机的发展,对差分格式与收敛条件的要求已经远不如从前那样 苛刻 ${ }^{[00]}$ ，直接用差分法来求解完备的原始方瑅已经相当普遍.

但是,物理湖泊学真正有生命力的领域是在湖泊水动力学, 湖泊热力学与湖泊光学三者与 湖泊环境与水生生物、植物生态学等的交错上. 用水动力学模拟的方法结合水体中其他物质的

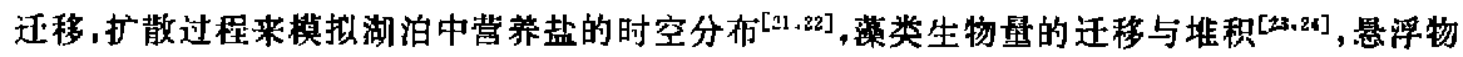
质的搬运与再悬浮等 ${ }^{[25]}$. 湖泊热力学研究的一个主要现象是湖泊分层与温跃层. 湖泊分层使

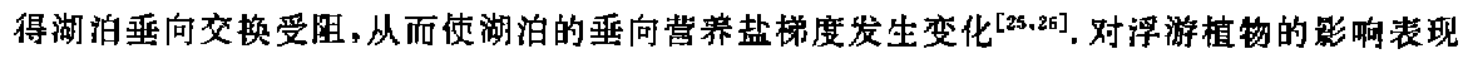
在 2 个方面, a) 温跃层深度与萍类最佳光适应深度的关系上 ${ }^{[27,28]}$, 这在深水湖泊非常重要，b)

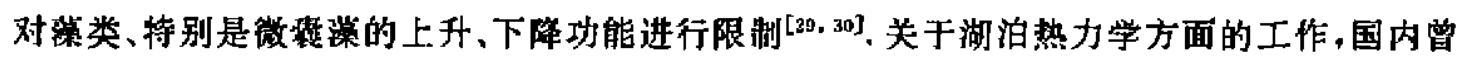
经开展了大量的抙查研究, 最近两年也出现了湖泊热力学方面的数值模拟研究 ${ }^{[31.32]}$. 湖泊光 学特性及水下光传输与光强度分布图对水体初级生产力影响很大而早在 70 年代就已引起人

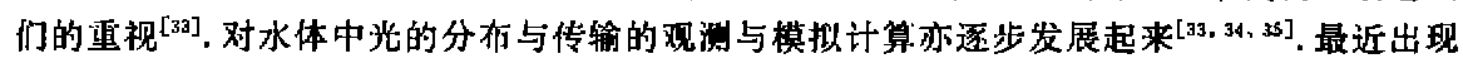
的生物一光学模式 (Bio-Optical model), 即用水体的光照分有来计算水体初级生产力 ${ }^{[36]}$, 花是 物理湖泊学与生物或生态学相结合的一个與型例子, 国内亦有这方面的研究报道 ${ }^{[3 r]}$.

\section{2 藻类生态学}

浮游植物,特别是藻类水华的形成机制及其与环境因子的关系是湖沼学中另一个较为活 跃的领域, 有关的文献亦较丰富. 这其中, 又可以分为二部分, 第一部分是有关浑游植物生长的 生理特点及其与湖泊物理环境 (特别是光、热等)的关系, 第二部分是关于薄类生长乃至買发与 环㑽园子, 特别是营养物质的关系. 关于第一部分, 主要集中在光分布与光强度与薯类生产力 的关系 ${ }^{[38.30]}$, 光能量在菜类光合与呼吸两个过程中屹传递的生理化学机制 ${ }^{[33]}$, 光辐射对营类 生长的限制方式、途径 ${ }^{[00]}$; 薄类细胞颜色对光吸收的生理机制 ${ }^{[41]}$; 以及藻类对光辐射变化响应 的时间尺度和生理机剩 ${ }^{[12]}$. 经过这一系列的研究, 使入们对于楞类生长熬殖过程中对于光能 基的依赖性及其生理机制等都有了一个较为全面的认识. 并出现了以落类响应于光变化为基

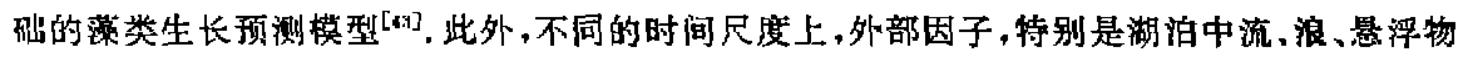
质等, 出现长期的变化趋势, 有可能使㳭类响应发生本质的变化, 即种群结构发生变化 ${ }^{[29,44]}$. 关于第二部分、即藻类生长与营养盐关系方面, 不如第一部分进展快. 人们都知道, 萝类特别是

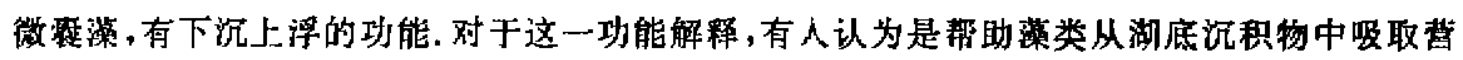
美[45]，原园是水一土界面上, 棠美盐浓度通常比湖水高; 也有人认为, 藻类的这种下沉功能, 可

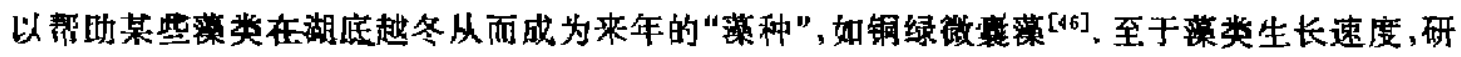


究表明,取决于萍类细胞的胞内磷 (P), 而不是胞外磷, 磷饥线细胞可在短时间内吸收大量的 磷而储存起来 ${ }^{[47]}$. 因此在水城中磷并不丰裕的情况下，使得其更具竞争力. 关于元元亲 $(N)$ ，研 究指出微整落也有较强适应能力, 即使在水中氮蚗乏时, 它也可以通过下沉上浮等方式或者降 低生长速率来适应环境中营美盐水平 ${ }^{[48]}$. 因而一般情况下, 当 N,P 不太丰富而易于成为其他 浮游植物限制因子时, 却成为有利于微装落生长发展的环境条件. 通过对北半球温带地区 200 多个湖泊的统计资料分析，发现在总磷 (TP)小于 $200 \mathrm{mg} / \mathrm{m}^{3}$ (即低营养水平下) 澡类叶绿素 a 与总磷 (TP) 的关系最好, 说明在这种情况下, 璘含量是棠类生长的限制因子, 但当 TP 大于

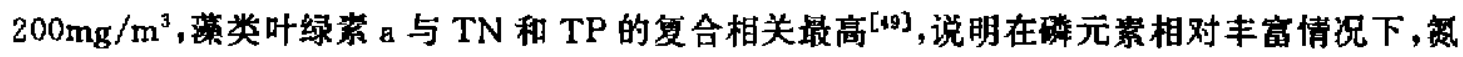
也可以成为一个限制因子. 至于 $N: P$ 多少时才是最适合, 目前尚无定论. 因为不同的研究者 得出的结论很不一致[48.50，51]，但是一般认为，低的 N I P 值、高温度条件、没有大量的浮游动 物提食等均会有利于落类大量繁殖 ${ }^{[52.53]}$.

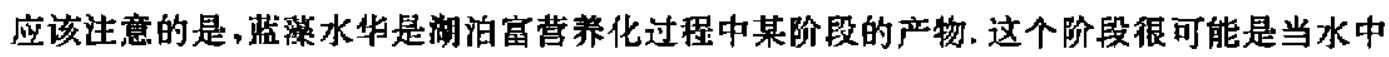
营养盐水平达到一定程度却又不十分充分的情况下由于蓝涤某些生理上的优势，使之成为该

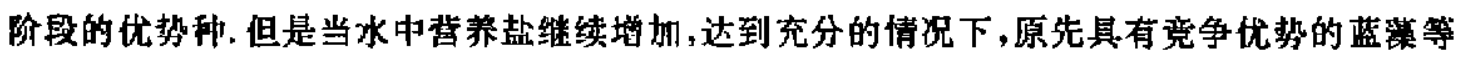
大型落逐渐失去其优势, 而光合表面积较大型㩰大的小型㩰在营养盐不受限制的情况下, 就有 可能成为优势种 ${ }^{[5]}$. 武汉东湖 ${ }^{[54]}$ 及太湖五里湖 ${ }^{[55]}$ 的演变情况提供了某种可能的旁证材料.

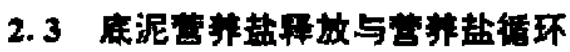

关于底泥营养物质释放与水中营养物质的循环, 这又是当今国际湖沼学研究中另一个异 炗活跃的领域. 通过近几十年来的研究，人们逐渐认识到底泥营养盐的释放是一个物理、化学 与生物综合作用的过程 ${ }^{[56]}$. 在湖底水一土界面上,既有向上的释放也有向下的沉降，前者如分 解，他化，扩散等; 后者如吸咐，凝聚等。当其净通量以下降为主时，底泥是一个汇，而当净通量 为释放时, 底浑为一个源 ${ }^{[5 ?]}$.一般认为由于底泥中 $\mathrm{P}$ 的浓度较湖水大, 从而形成一个向上的浓

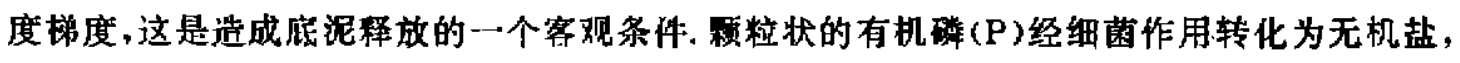
溶人孔腺水中,再经分子扩散、生物扰动、汽泡和水动力扰动等进人湖水中 ${ }^{[56]}$. 影响底泥中营 养盐释放的因素很多. 最重要的是沉积物中 Fe、Mn 元素的富集程度及水一土界面处的重化还 原环境. 早在本世纪 40 年代, 人们就已发现,沉积物中璘 (P) 的释放与沉积物表层 $\mathrm{Fe} 、 \mathrm{Mn}$ 元 素的成岩作用密切相关. 而 $\mathrm{Fe} 、 \mathrm{Mn}$ 的成岩作用又受控于革化还原环境 ${ }^{[58]}$ - 传统上描述璘释放 的化学模式是还原条件下有利于 $P$ 释放,而在曺化环境下有利于 P 沉积. 但近年来, 人们开始 认识到这一过程远比一个单纯的化学模式复杂得多。表现在对荧美元素释放机制的认识上， $\mathrm{Fe}$ 与 $\mathrm{Mn}$ 的反应机理是 $\mathrm{Mn}^{4+}$ 被 $\mathrm{Fe}^{2+}$ 还原为 $\mathrm{Mn}^{2+}$ 生成 $\mathrm{Fe}^{3+}$, 而微生物具备借助 $\mathrm{Mn}^{++}$或 $\mathrm{Fe}^{3+}$ 从有机化合物的羍化中获取能量以帮助生长 ${ }^{[s o]}$. 败生物作用结合化学与生物过程产生还原的 生物化合物如 $\mathrm{H}_{2} \mathrm{~S}$, 草䣼等, 从而通过包含在有机物质的矿化过程中直接或间接地调节 $\mathrm{Mn}$ 或 $\mathrm{Fe}$ 的氢氛化物的还原讨程 ${ }^{[00]}$ ，因而，人们看到的是 $\mathrm{P}$ 的矿化、释放与 $\mathrm{Mn} 、 \mathrm{Fe}$ 元素成岩作用关 系密切. 实际上, 用 $\mathrm{Fe}^{2+} / \mathrm{PO}_{4}{ }^{3-}$ 践 $\mathrm{Mn}^{2+} / \mathrm{PO}_{4}{ }^{3-}$ 值的高低就可以判断某一地区彴积物是 $\mathrm{P}$ 的源 (释放)还是汇 (视积 $)^{[6 !]}$.

影响磷释放的还有沉积物表是的无机铁第化物, 因为这些物质在 $\mathrm{pH}$ 呈中性的条件下, 能 吸咐阴离子. 在氧化的环境里. 这些物质充当了阻挡 $\mathrm{P}$ 元系从沉积物进人上復水中的阻砋

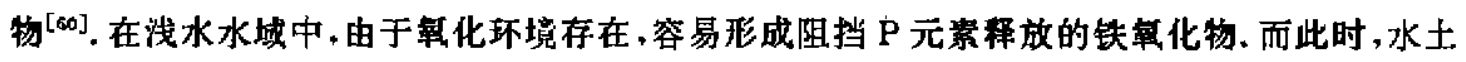


界面处的微生物则可能把大量的 P 冮存在细胞中, 并在环境转入还原状态时释放出来 ${ }^{\left[{ }^{[62} \text {. 反 }\right.}$ 过来, 在深水湖泊中, 由于其厌氧环境, 铁的氧化物的这种能力将受到前弱, 较有利于 $P$ 释放. 因此水土界面处氧化或还原条件对 $\mathrm{P}$ 的释放影㕰是比较大的. 这与 $\mathrm{N}$ 元素的释放中有类似 处. 水一土界面处如果氧供应较充分, 将强化沉积物与水界面处的反硝化过程, 并使 TIN(总

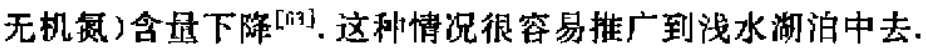

除了上述因甞外, 对底泥营美盐释放有影的的还有 $\mathrm{pH}$ 高低, 温度状况 ${ }^{[66]}$ 和水一土界面处 的水流状况 ${ }^{[65]}$. 在实际估计底泥营养盐释放时, 常常需要沉积物孔腺水与上磼水中营养盐的 浓度梯度变化, 从而可以估计其扩散量 ${ }^{[66]}$, 这一方法用在深水湖泊中是可以的. 但在浅水湖泊 中,目前未见有关报道出现.

综合上面 3 个方面 (水动力学、藻类生态学与沉积物化学)可以看到, 国际上的发展趋势以 学科相互渗透与交错为主. 如物理湖泊环境与落类生态行为、光适应性相结合, 灌类生态学与 分子生物学相结合.地球化学与微生物学相结合. 另外, 国际上对于上述三个领域中的研究已 经进入相当细致的地步. 有的是在分子水平上的研究, 手段、方法也越来越先进. 尽管在太湖进 行了近四十年的工作，但仍以谓查与评价为主. 对于一些过程与现象的机理研究不管. 相比之

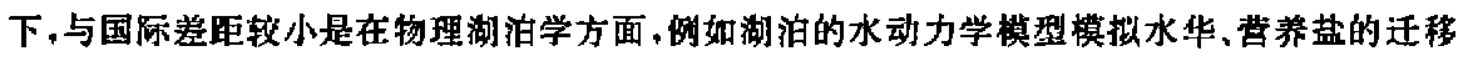

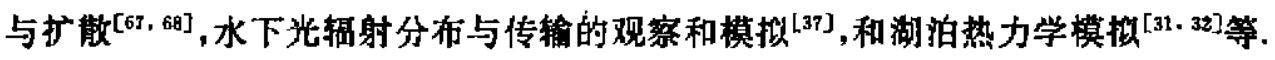

\section{3 “九五”工作的初步成果}

本期《湖泊科学收录的有关太湖的研究文章都是“九五”项目阶段性研究成果. 其中值得

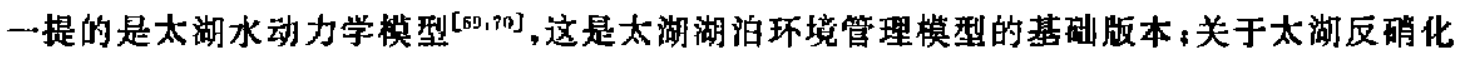
率的测定 ${ }^{[n]}$, 这是以前未曾沙及的领域,对于弄清钴循环必不可少、通过梅梁湾内与湾外落类 光合效率的对比，从而确定了梅梁湾内大量的蓝䔀生物曺并非是湾外迁移而来，而是湾内生长

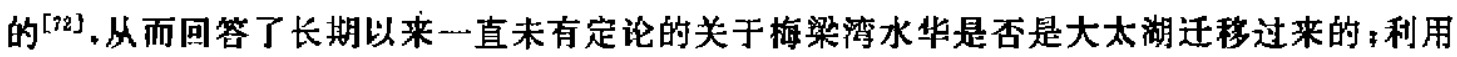
1998 年 2 月的 3 次天气过程、发现了梅梁㴽浮游动物数量与种群同温度、透明度的关系 ${ }^{[73]}$; 基

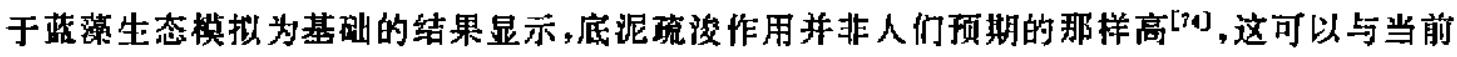
国示上就湖泊的氧化还原特性及与底泥营养盐释放的关系相对㚙. 除此之外、于 1998 年 7 月 进行的野外调查，进一步证实了梅梁唀在编南风作用下、表层流场以顺时针环流为主，从而间 接地说明了为升么每年夏季梅梁湾的东岸是落类水华容易堆积的地方; 分层测流的结果,亦再 一次明确无误地显示太湖尽管是一个浅水湖泊,但表层流场与底层流场结构不同, 流向有时是 反向的; 梅梁涭的类调查结果还显示,随着富营美化的加剧,种群在发生变化,个体呈现小型 化等等. 这些研究都正在整理之中, 相信“九五”项目的执行,将使我们对太湖水环境方面的认 识有一个大的进步.

\section{4 结语}

本文对太湖近四十年的研究作了一个简要的回顾. 展望未来,对于当前面临的主要生产实 际问题，提出了三个方面的研究工作作为“九五”期间太湖研究工作的重点. 这三个方面分别是

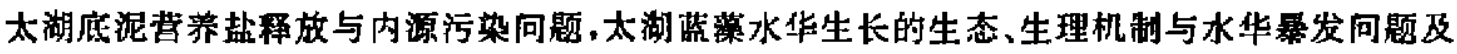
其太湖水环境管理的动力学模型. 与国际上在这三个领域中的研究相比, 我们的差距仍然很 
大.但也应看到，中国县发展中国家，所面临的湖泊富营养化是近十年才出现的环㑽问题. 就其 国内外研究而言，要言正认清湖泊富营养化机理，尚箩相当长的时间. 而这一问题又是政府管 理部门与生产部门非常关心，急待解决的问题. 因此,我们的工作既要为生产实际问题的解决 服务, 又要尽可能地与国际上相关领域的研究接轨, 缩小与国际水平的差距. 从“九五””期间开 展的研究工作来看,我们正朝着上述目标迈进.

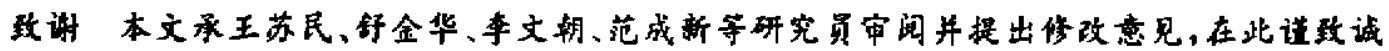
势的感诉。

\section{考文 献}

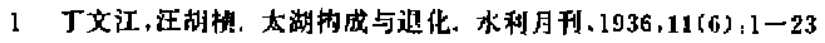

2 中国科学院南京地理哌究所. 太湖综合调查报告. 北京; 科学出股社, 1965.1-81

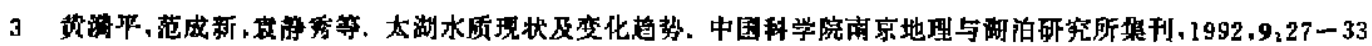

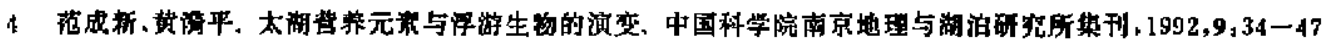

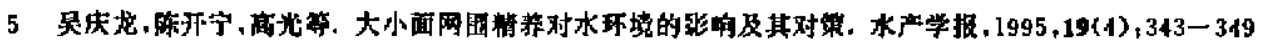

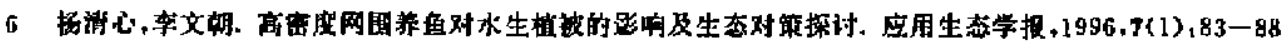

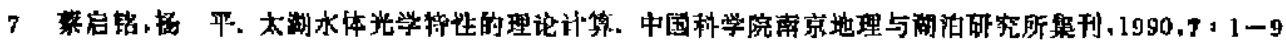

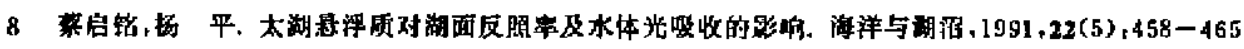

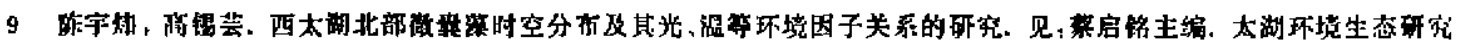
(一). 北京、气象出版社.1998. 142-148

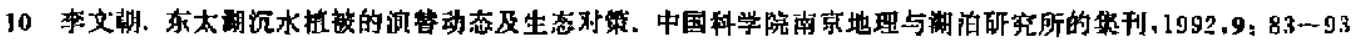

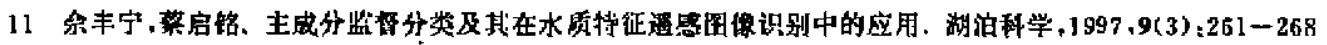

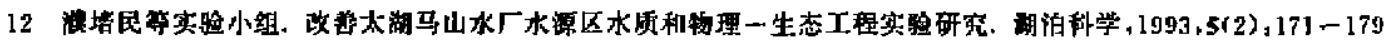

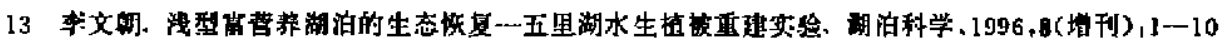

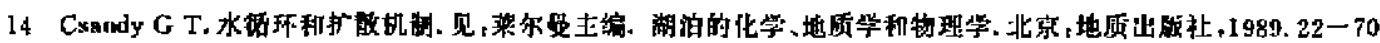

15 Kanari S. The long term period internal waves in Lake Biwa. Limnod Oteasogr, 1975. 20(4), 544-553

16 Bauejle E. Internal free oscillations in the lake Geneva. Ann Gesphysicur, 1985, 3.199-205

17 Horn W, C H Mortimer, D J Schwab. Wind induced internal seiches in Lake Zurich observed and modelled. Limmot Oieanogr, 1986, 31:1232-1254

18 Stoker K, K Hurter. G SAlvade, et at. Observation snd analysis of internal seichey in the southern bssin of Lake Lugano. Arn Geophysicur, 1987, 5B(6), 553-558

19 Hutter K. Large ncale water movements in lakes. Aquatic Sciences, 1991, 53(2/3), 100-133

20 Casulli V. Numerical simulaxion of shallow water flow, In, Gambolati, et al eds. Proceeding” of Eighth International Conference on Computationa] Methods in Water Resourcer. Computational Mechanica Publicntions, 1990. 13-22

21 Hutter $K, Y$ Wang. Computation of wind driven circulation and tracer diffusion in lakes with a semi-implicit semispectral primitive equarion model. Jusnat of Compustationat Physics, 1998 (in press)

22 Pfeiffer K D. K C Duwe. Modelling of environment and water-quality relevant processes with combined Eulerian and Lagrangian Modely. In: Gambolati. of wi eds. Proceedings of Eighth International Conference on Computational Methods in Waver Resources. Computationat Mechrsnica Publications, 1990. 113-118

23 Webater $1 \mathrm{~T}$. Effects of wind on the diatribution of phytoplankton in take revisited. Limant Oceanogr, 1994, 39(2), $365-373$

24 Verhagen J H G. Modelling phytoplankton patchiness under the influence of wind-driven currenta in lakes. Limnux 
Ocrenogr. 1994. 39( $(\tau), 1551-1565$

25 Wang S S Y. The state of the nrt on FE modelling of 3D sedimentation processen. In, Gambolati, at at eds. Proceedings of Eighth International Conferencc on Computational Methods in Water Renources. Computntional Mechannics Publications. 1990. 265-280

26 Span D, J Dominik. M A Lhzzaretti, at at. The role of sediment in phosphorus cycle in lake Lugano I. Geochernical нрp rosch. Atprutic Sciences, 1992, 54(3/4), 277-284

27 Imboden D M. Mixing and trankport in laken, mechanism and ocological relevance. In, Tilzer and Serruyn eds. L.nrge Lakes - Ecolugieal Structure and Function. Berlin, Brocks/Springer Serieu in Comtemparary Biosciences, 1990. 47-80

29 Perterson J C. Model ling the effects on primary production in the mixed Inyer of lakes. Aqratic Sciences, 1991, $53(2 /$ 3), $218-238$

29 Reynolds C S, E G Bellinger. PAtternn of abondance and domimance of the phytoplankton of Rostherne Mere, England, evidenee fram a 18.year data set. Aquatsc Stiences. 1992. 54(1), 10-35

30 Habson L-A. Algal recruitment from Iake sediments in rclation to grazing, Binking, and dominance patterns in the plyytoplankton community. Limes Ocedsagr, 1996, 41(6), 1312-1323

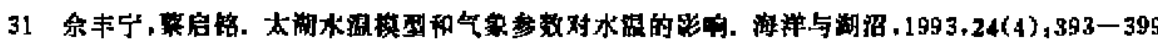

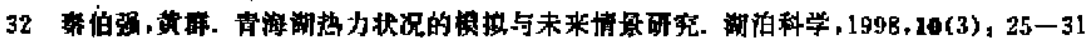

33 Hrll D O, K K Rno. Photonysthesis. Stadirs in Biodogy, 1977, 37, 1-71

34 Jonase M. H Prandke. Comparixon of measured and computed light scartering in the Baltic. Trilas, 1986, 396, 144152

35 Gordan H R, O B Browm. A theoretical model of light wcattering by Sargasso Ses particulates. Limnot Ocramogr, $1972,17,826-932$

36 Smith R C, B B l'reaclin, R R Bidigare, et al. Bio-optical modelling of photonysthetic production in constnl waters. Limeul Diranogr. 1989. 34(B), 1524-1544

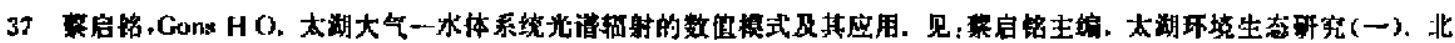
京、气象出版杜, 1998. 5 - 18

38 Falkowaki P G, Z Dutinsky, K Wyman. Growth-irradiance relationship in phytoplnnkton, Limnof Oceuvogr, 1985, 30: $311-321$

39 Kirk J T O. Light and phoronysthesis in nquatic econystems. Cambridge, Cambridge Univeraity Press, 1983

40 Tizler M M. Environmental and physiological control of phytoplankton productivity in large lakes. In, Tilzer and Serruya eds. Large Lukes - Ecological Sțructure and Function, Berlin, Brocks/Springer Series in Contemporary Biosciences, 1990, 339-367

41 Prezelin B 13. $M M$ Tilzer, O Schotield. The control of the production process of phytoplankton by the physical structure of the Aqntic envirqument with npecial reference to its optical propertien. Aquatic Scirnces, 1991, 53(2/3) , 136 $-186$

42 Ferries J M, R Chriarian. Aquntic primary production in relation to microalgal responae to changing light; a review. Apratir Sciences, 1991 , 53(2/3), 187-217

43 Denman K L., J Marra, Modelling the time-dependent photordaption of phytoplankton to fluctuating light. Elsroirr Otramngr, 1986, Ser 42, 341-360

14 Bleiker W. F Schanz. Light climate an the key factor conrrolling the spring dynamick of phytoplankton in Lake Zorich. Apactic Sciences, 1997, 59, 135-157

45 Sirenko L. A. The effects of the blue-green algae on forma sion of algal commanitien and on water quality in the Dairper Renerwoir. Arch Hydrobiol Beah Ergebn Lismal, 1987, 25, 39-49

46 Takamura N, M Yanuno, K Sugathara. Overwintering of Micnocyatis nerwginase kutz in a shation lake. J Plawktow Res, 1984, $6(6), 1019-1029$

47 Okado M, R Sudo. Nutrienr nhapption and growth claracterinties of Microcystis aeruginose. Res Rrp Natiand Inst 
Environ Stadies, $1979,61293-302$

48 Smith V H. Low nitrogen to phosphorus ratios favor dominance hy hlue-green algae in lake pliytoplankton, Scirnce, $1983,221: 669-671$

49 Seip K L. Phosphorus and nitrogen limirarion of algal hiomass across trophic gradients. Agtutuc Sciences, 1994 . S6 1), $116-128$

50 Dillon P J, F H Rigler. The phoнphorus-chlorophyll relationship in lakes. Linmol Oceanogr, 1974, 19: 767-773

51 Ernht A. Cyanobacteria in large lakes; a case study in Lake Constance. In. Tilzer and Serruya eds. Large Lakes Ecological Structure and Function. Berlin. Brocks/Springer Series in Contemporary Bicsciences, $1990.428-439$

52 McQueen D J, D R S Lean. Influence of water temperarure and nitrogen to phosphorus rario on the dominance of hivegrecn algae in Lake Si. Geoge, Ontario. Cun of Fish Aqua Sci, I 587, 44: 598- 604

53 Haney J F. Field studies on zooplankton-cyanobacteria interaction. New Zeat $\int$ Mari Freshwater Res, 1987,21.467475

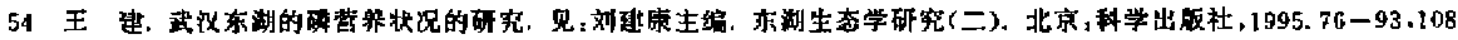
$-128$

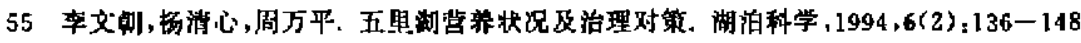

56 Sediment Plosphorus Group. Working sumrary and proposals for future research. Arch Hydrobiol Beith Ergedn. 1988. 30, $83-112$

57 Dillon P J, L. A Molot. Long-term phosphorus budgets and an examination of a steady-stare mass balance model for cenrral Ontario Lake. Wuter Research, 1996. 30(10): 2273-2280

58 Mortimer C H. The exchange of dissolved substances between mud and water in lakes. Int $J$ Ecot . 1941, 29: 280-329

59 Losley D R. J F Stolz, G L Nord. ef al. Anaerobic production of magnetite by a dissimilatory imn-reducing microorganism. Nature. $1987,330: 252-254$

60 Lazzretri M A.KW Hanselmann, at al. The role of sediemnrs in the phosphorus cycle in large lake Lugan, $I$. Heasonal and spatial variability of microhiological processes at the sediment-warcr interlace. Afuutic Sciescrs. 1992. S4 $(3,4): 285-299$

61 Span D. J Dominik, M A Lazzaretti, et ad. The role of sediemnts in the phosphorus cycle in large lake I.ugano, 1 : Geochemical appronch. Aqwatic Sciences, $1992,54(3 / 4): 277-284$

62 Gachter R. IS Meyer, A Mares. Contribution of bacterin to rolease and fixation of phosphorus in lake sediemnts. Limient Ocranogr, 1988. 33: 1542-1558

63 Hohener P. R Gachter, Nitrogen cycling across the sediemnt-water inrerface in an eutrophic, arrificially oxygenated lake. Afratic Scientes, 1994, 56(2): 115-13)

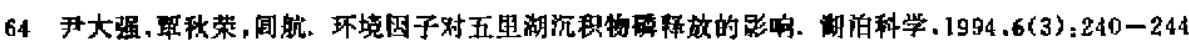

65 Lea $\mathrm{H} \mathrm{G}, \mathrm{C}-\mathrm{H}$ Duyang. J-I, Su. Elfects of flow velociry changes on nitrogen rransporr and conversion in an open channel flow. Water Rexeurch, 1996, 30(9): 2065-207)

66 Urban N R, C Dinkel, B Wehrli. Solute rransfer acroes the sedimenr surface of a eutrophic lake, I. Porewater profiles from dialysis samples. Aqwatic Sciestes. 1997. 59, $1-27$

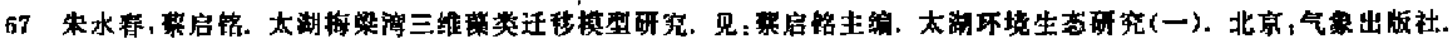
1998. $169-177$

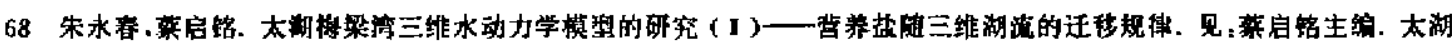

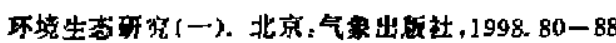

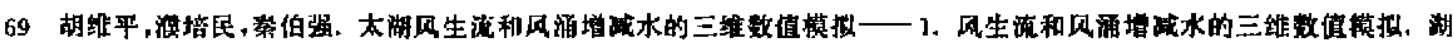
诣科学, $1998,10(4), 17-25$

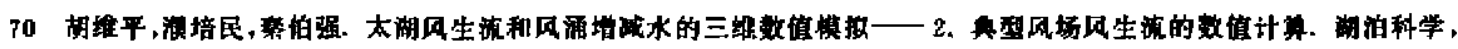
$1998.16(4): 26-34$

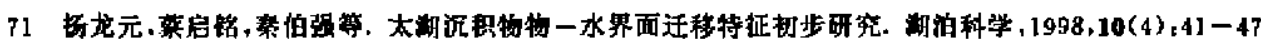




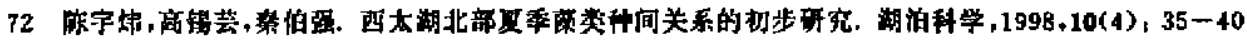

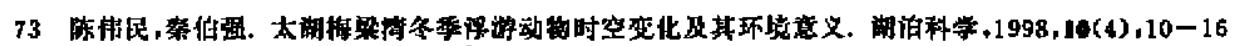

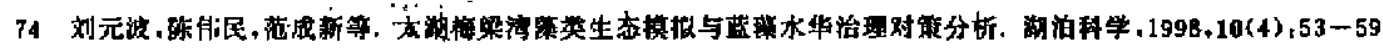

\title{
A Review and Prospect about the Aquatic Environment Studies in Taihu Lake
}

\author{
Qin Boqiang \\ (Nanjing Instufute of Geagraphy \& Limndugy, Chonese Acadenty of Sciences. Nanjing 210008)
}

\begin{abstract}
Taihu Lake is a large and shallow lake located in the delta of the Changjiang River. It is an importment lake since it undertakes the drinking water supply, the transportation, sightseeing and culturing. In the last decade, this lake is suffering from the eutrophication caused by industrialization around the lake area. This paper attempts to summarize the research activities and conclusions in Taihu Lake in the past several decades. According to the current urgent requirements of the countermeasures to harness deterioration of lake environment suggested by the government, some key problems that should be addressed in the Ninth 5-year Plan are put forward, i. e. the lake management model which will be based on the hydrodynamic processes coupled with the diffusion and migration processes of nitrient and algac, the mechanism of the occurrence of Cyanobacteria bloom, the release of nutrients from sediments. By the survey of literature in the international journals, a prospect about the relevant topics have been reviewed and the wantings have been revealed. Finally, the primary conclusions of the ongoing research projects have been summarized.
\end{abstract}

Key words Taihu Lake, environmental change, review, prospect 